S. K. Iskander, ${ }^{1}$ R. K. Nanstad, ${ }^{1}$ C. A. Baldwin, ${ }^{1}$ D. W. Heatherly, ${ }^{2}$ M. K. Miller, ${ }^{1}$ and I. Remec $^{3}$

\title{
Reirradiation Response Rate of a High-Copper Reactor Pressure Vessel Weld
}

Reference: Iskander, S. K., Nanstad, R. K., Baldwin, C. A., Heatherly, D. W., Miller, M. K., and Remec, I., 'Reirradiation Response Rate of a High-Copper Reactor Pressure Vessel Weld," Effects of Radiation on Materials: 20 ${ }^{\text {th }}$ International Symposium, ASTM STP 1405, S. T. Rosinski, M. L. Grossbeck, T. R. Allen, and A. S. Kumar, Eds., American Society for Testing and Materials, West Conshohocken, PA, 2002.

\begin{abstract}
The Charpy impact response of reirradiated Heavy-Section Steel Irradiation (HSSI) Program Weld 73W has been determined at three fluence levels. The Charpy specimens had previously been irradiated at $288^{\circ} \mathrm{C}$ to $1.8 \times 10^{19} \mathrm{~cm}^{-2}(\mathrm{E}>1 \mathrm{MeV})$ and annealed at $454^{\circ} \mathrm{C}$ for $168 \mathrm{~h}$. The results show that the change in the 41-J Charpy energy level transition temperature $\left(\mathrm{OTT}_{41-\mathrm{J})}\right.$ of the reirradiated specimens is slightly higher than predicted by the vertical shift method, but significantly less than predicted by the lateral shift method. Previous results have also shown that the upper-shelf energy (USE) over-recovers as a consequence of annealing, which may explain why the USE value after a significant amount of reirradiation is approximately equal to the USE value in the unirradiated condition.
\end{abstract}

Keywords: annealing, reactor pressure vessel, Charpy V-notch, irradiation, neutron, weld metal, copper

\section{Introduction}

A consideration in the decision to anneal a reactor pressure vessel (RPV) is the reembrittlement rate after annealing. This response is important in order to assess the cost-to-benefits ratio of restoring fracture toughness properties of RPVs that have been degraded by neutron irradiation. There is a dearth of fracture toughness data on reembrittlement rates, and the use of Charpy data may be a useful indicator of such rates. It is

${ }^{1}$ Metals and Ceramics Division, Oak Ridge National Laboratory, P.O. Box 2008, Oak Ridge, TN 37831

${ }^{2}$ Engineering Technology Division, Oak Ridge National Laboratory, P.O. Box 2009, Oak Ridge, TN 37831

${ }^{3}$ Computational Physics and Engineering Division, Oak Ridge National Laboratory, P.O. Box 2008, Oak Ridge, TN 37831 
assumed that the rate of toughness degradation upon reirradiation may be assessed by means of the 41-J temperature shift (OTT ${ }_{41-\mathrm{J}}$ ) and the USE drop (OUSE) of the Charpy impact energy curve.

A few years ago, there was much research on the topic of thermally annealing RPVs [1],[2],[3],[4],[5]. About a dozen RPVs were annealed in Eastern Europe [6], a process which was followed with much interest in the United States, and the principal author of this paper participated in one of the delegations composed of U.S. Nuclear Regulatory Commission (NRC) staff, industry, and research groups that visited the site of the Novovorenzh Nuclear Power Plant, Unit 3, and its annealing [7]. During this period an amendment was made to 10CFR50.66, "Thermal Annealing Rule," NRC Regulatory Guide 1.162 on Annealing [8] was issued, and American Society of Mechanical Engineers (ASME) Code Case N-557 on dry annealing of a nuclear RPV was published [9]. Models for the recovery of the transition temperature and USE were published [10] with the help of a database assembled at Oak Ridge National Laboratory (ORNL) [11]. The American Society for Testing and Materials (ASTM) Standard Guide for In-Service Annealing of Light-Water Cooled Nuclear Reactor Vessels, ASTM 509-97 was revised to address annealing recovery and reembrittlement. Recently this activity has subsided, in part because of economic issues. However, since research with irradiated material takes many years, it would be prudent to continue research on developing an understanding of reembrittlement rates. A major revision of NRC Regulatory Guide 1.99, Rev. 2 [12] is being considered that would effect the pressurized thermal shock (PTS) screening criteria $\left(\mathrm{RT}_{\mathrm{PTS}}\right)$. Moreover, the methodology for determining $\mathrm{RT}_{\mathrm{PTS}}$ is being evaluated, and these events could have an impact on whether any plants would ever be candidates for annealing.

\section{Material Used in this Study}

High-copper HSSI Weld 73W has been very extensively characterized in the unirradiated and irradiated conditions [13]. A relatively large number of specimens were tested in the unirradiated and irradiated conditions such that statistical data on the effects of neutron irradiation on Charpy, tensile, initiation and crack-arrest fracture toughness have been published. These results have established a correlation between the irradiation-induced shifts in fracture toughness and Charpy $\mathrm{OTT}_{41-\mathrm{J}}$, and it is assumed that such a correlation continues in the reirradiated case.

For reference, the chemical composition and mechanical properties of Weld $73 \mathrm{~W}$ are shown in Tables 1 and 2, respectively.

Table 1 - Chemical composition and the standard deviation of the various elements of HSSI Weld $73 \mathrm{~W}$

\begin{tabular}{|c|c|c|c|c|c|c|c|c|c|c|}
\hline \multicolumn{11}{|c|}{ Composition, wt $\%$, and standard deviation } \\
\hline & $\mathrm{C}$ & $\mathrm{Mn}$ & $\mathrm{P}$ & S & $\mathrm{Si}$ & $\mathrm{Cr}$ & $\mathrm{Ni}$ & Mo & $\mathrm{Cu}$ & $\mathrm{V}$ \\
\hline Mean & 0.098 & 1.56 & 0.005 & 0.005 & 0.45 & 0.25 & 0.60 & 0.58 & 0.31 & 0.003 \\
\hline
\end{tabular}




\begin{tabular}{|c|c|c|c|c|c|c|c|c|c|c|}
\hline Standard & 0.007 & 0.026 & 0.000 & 0.000 & 0.028 & 0.006 & 0.006 & 0.009 & 0.010 & 0.000 \\
\hline Deviation & & & 4 & 6 & & & & & & 1 \\
\hline
\end{tabular}

Table 2 - Mechanical properties of HSSI Weld 73 W

\begin{tabular}{|c|c|c|c|c|}
\hline \multirow[t]{2}{*}{ Material } & \multirow{2}{*}{$\begin{array}{c}\text { CVN impact } \\
\text { USE } \\
(\mathrm{J})\end{array}$} & \multirow{2}{*}{$\begin{array}{l}\text { CVN 41-J } \\
\text { transition } \\
\text { temperature } \\
\left({ }^{\circ} \mathrm{C}\right)\end{array}$} & \multicolumn{2}{|c|}{$\begin{array}{l}\text { Room temperature } \\
\text { tensile strength } \\
(\mathrm{MPa})\end{array}$} \\
\hline & & & Yield & Ultimate \\
\hline $\begin{array}{l}\text { HSSI weld 73W } \\
\text { (undersize specimens) }\end{array}$ & 118 & -38 & 495 & 603 \\
\hline $\begin{array}{l}\text { HSSI weld } 73 \mathrm{~W} \\
\text { (full size specimens) }\end{array}$ & 135 & -40 & 495 & 603 \\
\hline
\end{tabular}

There were a number of slightly undersize Charpy specimens used in the irradiation, annealing, and reirradiation studies. As may be seen from Table 2, there is very little difference between the 41-J transition temperatures $\mathrm{TT}_{41-\mathrm{J}}$ of the full-size and undersize specimens and thus in reference to the $\mathrm{TT}_{41-\mathrm{J}}$ no distinction will be made regarding specimen size. The results of testing unirradiated, irradiated and annealed Charpy specimens are shown in Fig. 1. An interesting observation is that the USE has over-recovered to levels higher than the original unirradiated value. Unirradiated specimens were aged at $454^{\circ} \mathrm{C}$ for $168 \mathrm{~h}$ and increases in the USE were also observed for these specimens. This has been frequently reported in the literature, but is nonetheless unexpected since HSSI Weld 73W had been stress relieved at $607^{\circ} \mathrm{C}\left(1125^{\circ} \mathrm{F}\right)$ for $40 \mathrm{~h}$, which is typical for welds in commercial RPVs. This has also been confirmed by plotting the percent recovery of the USE versus percent recovery of $\mathrm{TT}_{41-\mathrm{J}}$ as shown in Fig. 2, which was prepared from data in Ref. [11]. The reason for this over-recovery is still unknown. The relationship shown in Fig. 2 between recovery of the $\mathrm{TT}_{41-\mathrm{J}}$ and over-recovery of the USE implies that if the $\mathrm{TT}_{41-\mathrm{J}}$ recovers, then the USE will also recover percentage-wise at least as much.

\section{Reirradiation, Dosimetry and Testing of the Charpy Specimens}

Three containers, each with ten Charpy specimens, and 0.5-mm-diam (0.020-in.) Fe and $0.1 \% \mathrm{Co} / \mathrm{Al}$ wire dosimeters in the $\mathrm{V}$-notch grooves of the specimens were encapsulated in three containers, as shown in Fig. 3. The three containers were electrodischarge machined from solid aluminum stock. The tolerances on the inside and outside dimensions of the containers were required to be very small. The specimens had previously been irradiated to an average fluence of $1.8 \times 10^{19} \mathrm{~cm}^{-2}(\mathrm{E}>1 \mathrm{MeV})$ and then annealed at $454^{\circ} \mathrm{C}$ for $168 \mathrm{~h}$. The packaging of the irradiated specimens and the dosimeters, using manipulators in the hot cell, required high dexterity of the ORNL operators. The three containers were then loaded with three fission radiometric dosimetric sets (FRDS), in the HSSI Program/University of California, 
Santa Barbara (UCSB) capsule located at the University of Michigan Ford Nuclear Reactor (FNR) and reirradiated to $0.4,0.8$, and $2.95 \times 10^{19} \mathrm{~cm}^{-2}(\mathrm{E}>1 \mathrm{MeV})$ at $288^{\circ} \mathrm{C}$. The specimens irradiated to these fluences will be referred to as the low-, medium-, and high-flux Charpy specimens (see Fig. 4). 


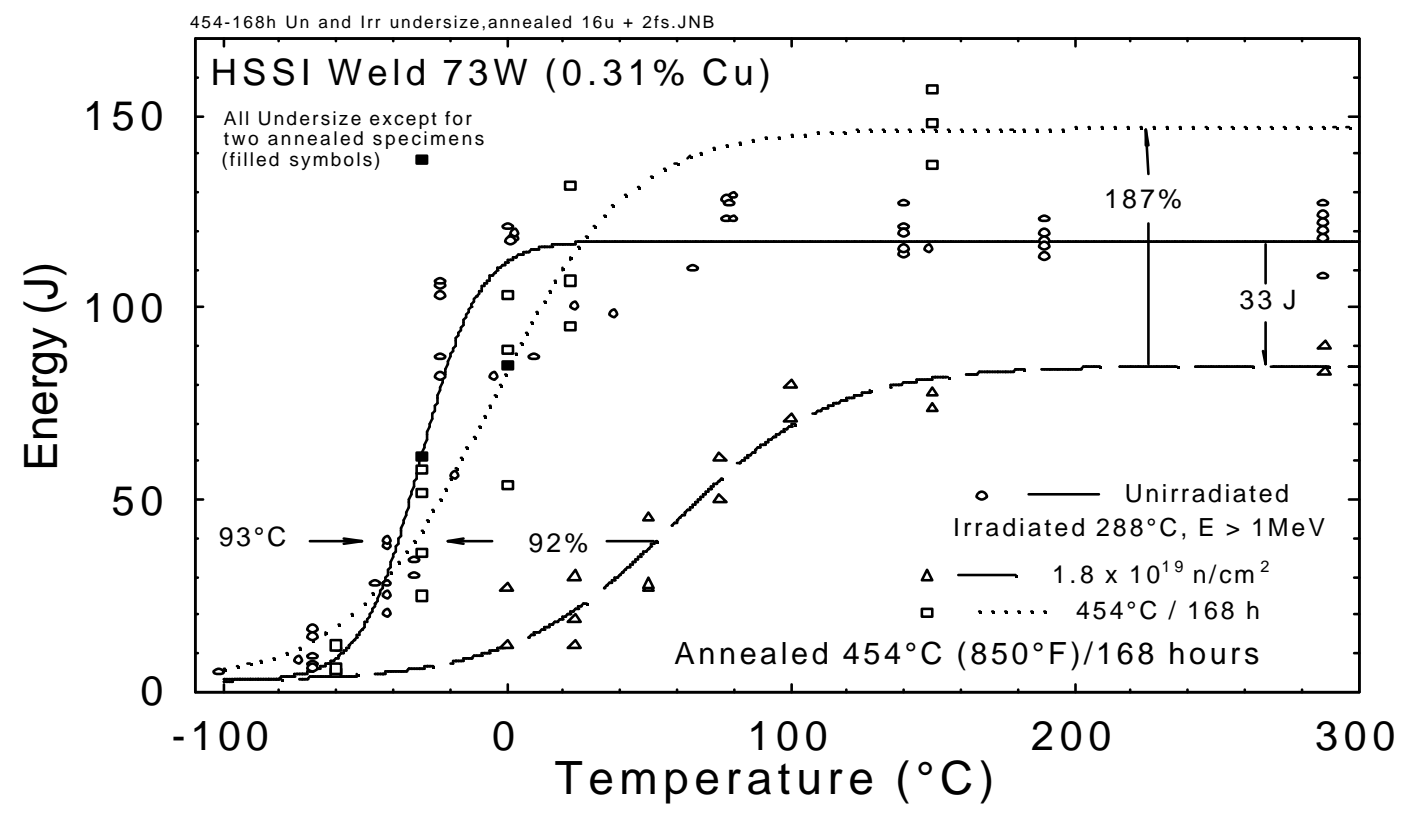

Figure 1 - The results of testing unirradiated, irradiated, and annealed Charpy specimens.

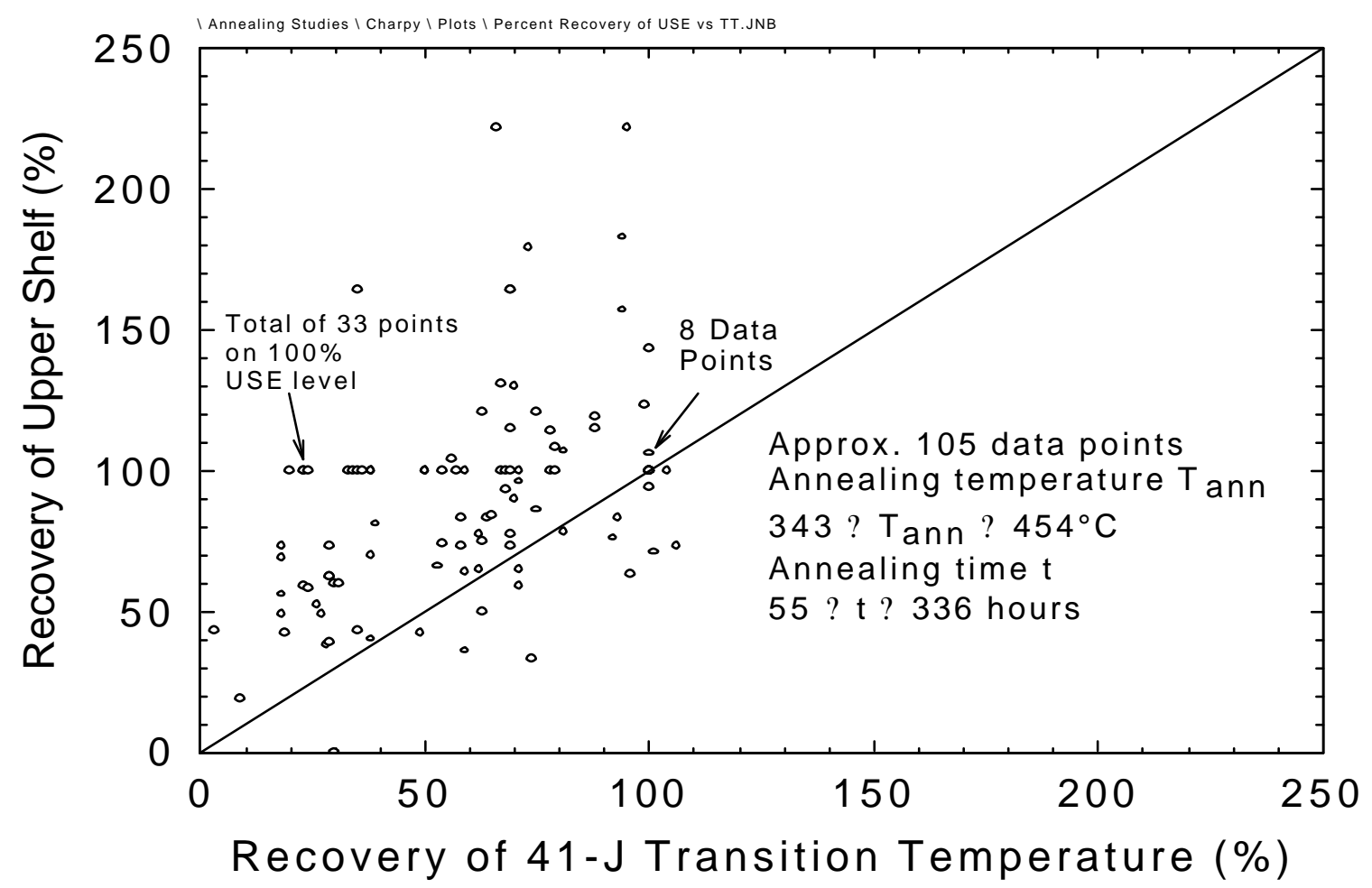

Figure 2 - The recovery of the USE versus percent recovery of $T T_{41-\mathrm{J}}$. 


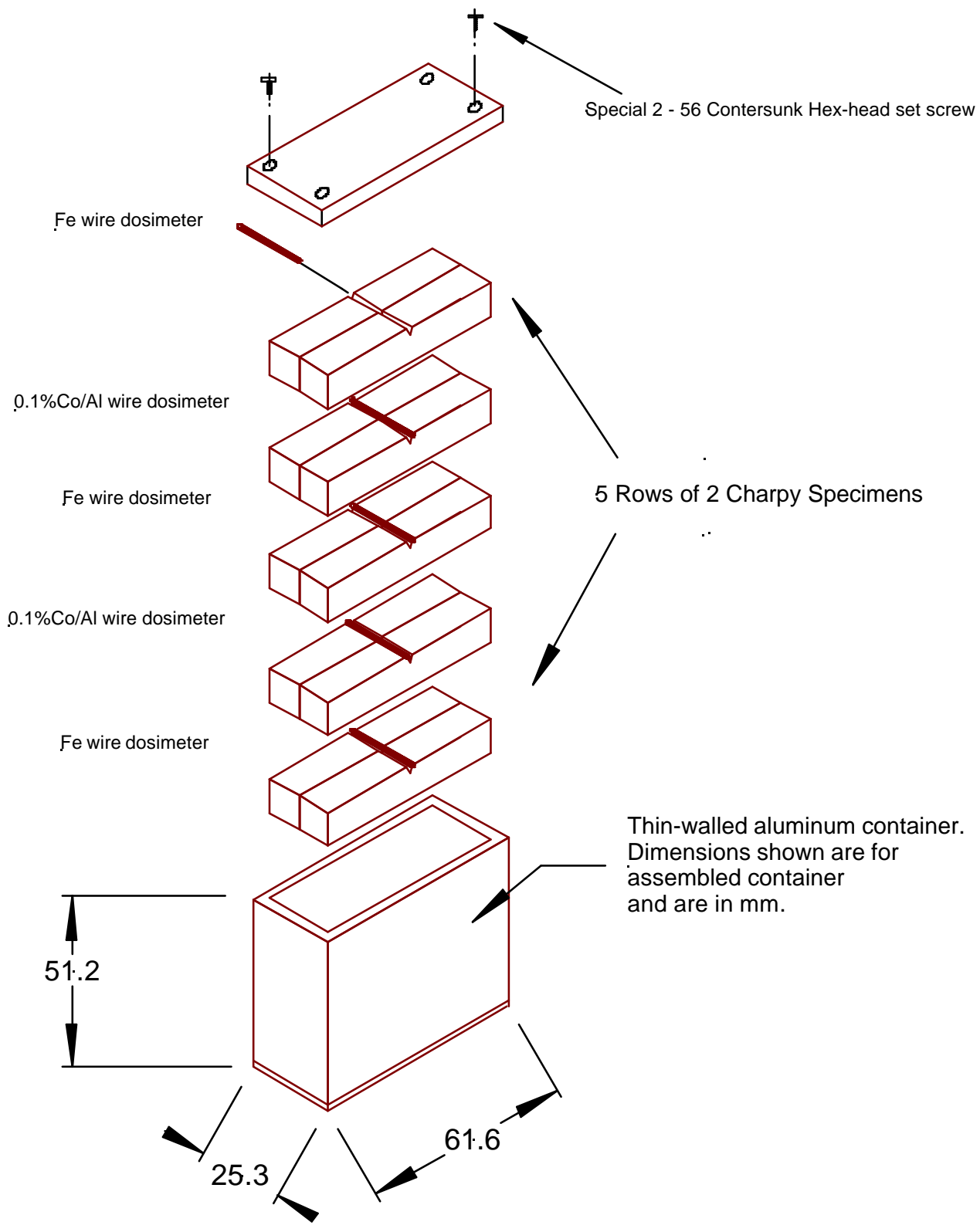

Figure 3 - Charpy specimens were encapsulated in three containers with 0.5-mm-diam (0.020-in.) $\mathrm{Fe} 0.1 \% \mathrm{Co} / \mathrm{Al}$ wire dosimeters in the V-notch grooves of the specimens. 


\section{HSSI/UCSB Charpy Packets}

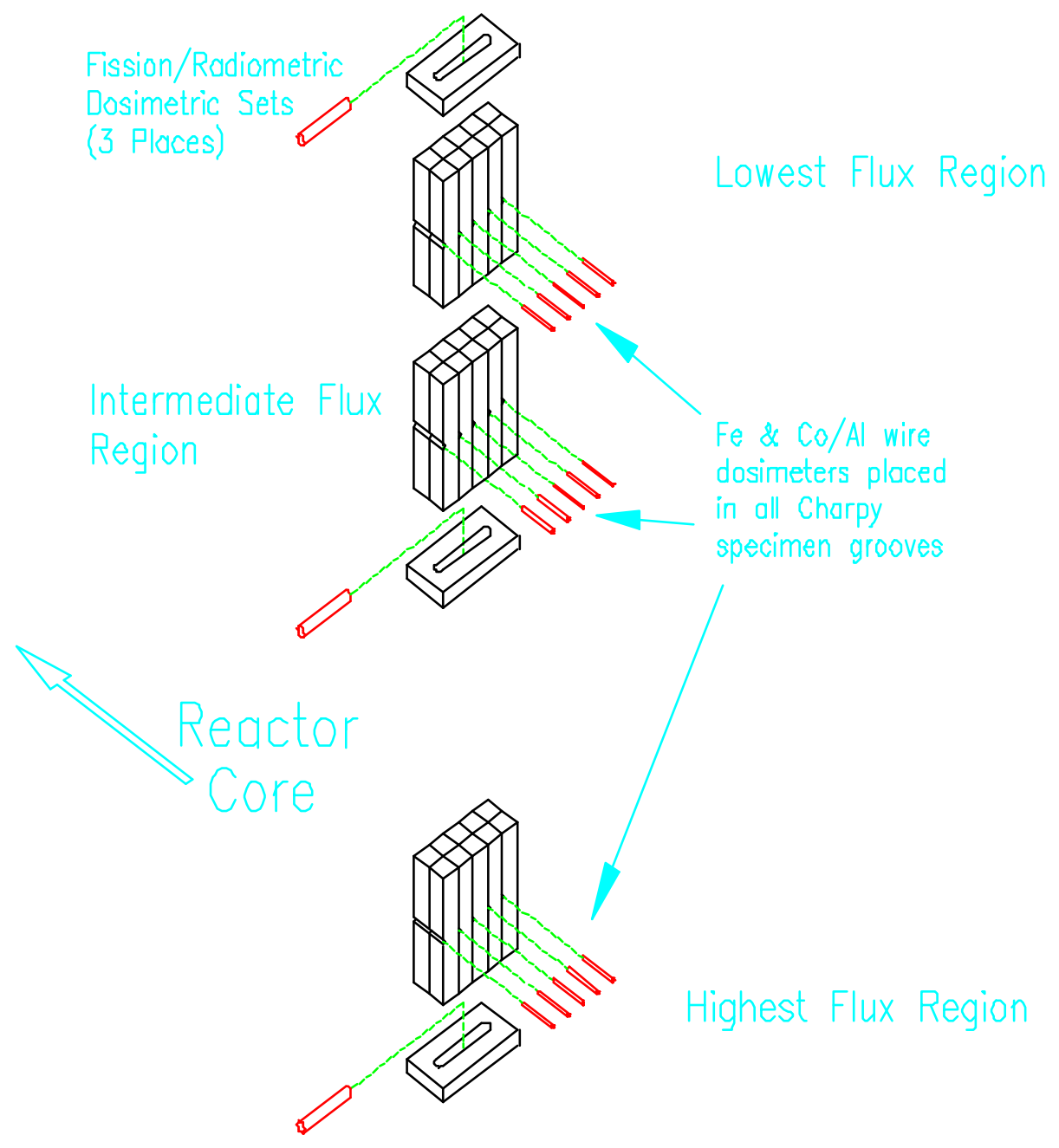

Figure 4 - Arrangement of the three Charpy specimen containers in the University of Michigan Ford Nuclear Reactor. 
The FRDS were retrieved after about 20 days of irradiation and used to estimate the flux. The duration of irradiation exposure required was then estimated, the irradiation completed and the containers retrieved, and the activity of the wire dosimeters counted. The low-flux containers were located at a higher elevation than the reactor core, and it was necessary to perform three-dimensional dosimetric calculations because preliminary calculations of flux made using an approximate three-dimensional analysis (with an estimated error of less than $10 \%$ ) showed that the calculated flux was $20 \%$ lower than the initial three-dimensional estimates.

The results of testing the Charpy specimens are shown in Fig. 5, which is composed of four plots, labeled (a) Charpy energy, (b) percent shear, (c) lateral expansion as a function of temperature, and (d) Charpy energy as a function of lateral expansion. The lateral expansion is difficult to measure in the hot cell, so plots (c) and (d) helped identify potential error to be corrected by remeasurement. The USE of the reirradiated material is still as high or higher than the unirradiated value.

The shifts in $\mathrm{TT}_{41-\mathrm{J}}, \mathrm{OTT}_{41-\mathrm{J}}$, for the irradiated, annealed, and reirradiated (IAR) specimens have been plotted as functions of the total fluence in Fig. 6, in which the coordinates of the experimental points have been given between parentheses [shifts in $\mathrm{K}$ and total fluence in $\left.10^{19} \mathrm{~cm}^{-2}(\mathrm{E}>1 \mathrm{MeV})\right]$. The initially irradiated $\mathrm{OTT}_{41-\mathrm{J}}$ data are labeled $\mathrm{I}$, the irradiated and annealed results are labeled IA, and the three reirradiated values are labeled IAR. Two methods of estimating the reirradiation rates are described in ASTM E 509. The vertical shift method assumes that the change in embrittlement due to reirradiation follows the same function of total fluence as if irradiation continued with no annealing, and is shown as the dotted curve in Fig. 6. The lateral shift method assumes that embrittlement due to reirradiation continues follows the same function of increase in fluence as the unirradiated material and is shown as the dashed curve. It may be seen that the measured values of OTT $_{41-\mathrm{J}}$ are well below the values predicted by the lateral shift method, but are somewhat higher than the values predicted by the vertical shift procedure.

To estimate the rate of reembrittlement beyond the largest fluence, the rate predicted by the fluence factor given in Regulatory Guide 1.99, Rev. 2, was used with the chemistry factor adjusted until the curve, shown as a dash-dot in Fig. 7, passed through the OTT $_{41-\mathrm{J}}$ at the accumulated fluence of $4.8 \times 10^{19} \mathrm{~cm}^{-2}(\mathrm{E}>1 \mathrm{MeV})$. The chemistry factor obtained implies an effective copper content of about $0.02 \%$, for the $0.6 \% \mathrm{Ni}$ of HSSI Weld 73 . It may be recalled that the actual total copper content of this weld is $0.31 \%$.

A curve of the $\mathrm{OTT}_{41-\mathrm{J}}$ vs $\mathrm{OO}$ was regression fit through the four data values associated with IA, and IAR; this has also been plotted in Fig. 7 as a dash-dot-dot curve. This curve can be used to predict the $\mathrm{OTT}_{41-\mathrm{J}}$ for a set of ten specimens now being reirradiated at the FNR to an accumulated total fluence of about $6 \times 10^{19} \mathrm{~cm}^{-2}(\mathrm{E}>1 \mathrm{MeV})$.

The Kurchatov Institute in Moscow, Russia, has performed similar experiments, and their results have also been plotted in Fig. 6 [14]. The lack of agreement between the Kurchatov and ORNL results at approximately the same fluence is obvious, but the reasons for this difference are not known. 


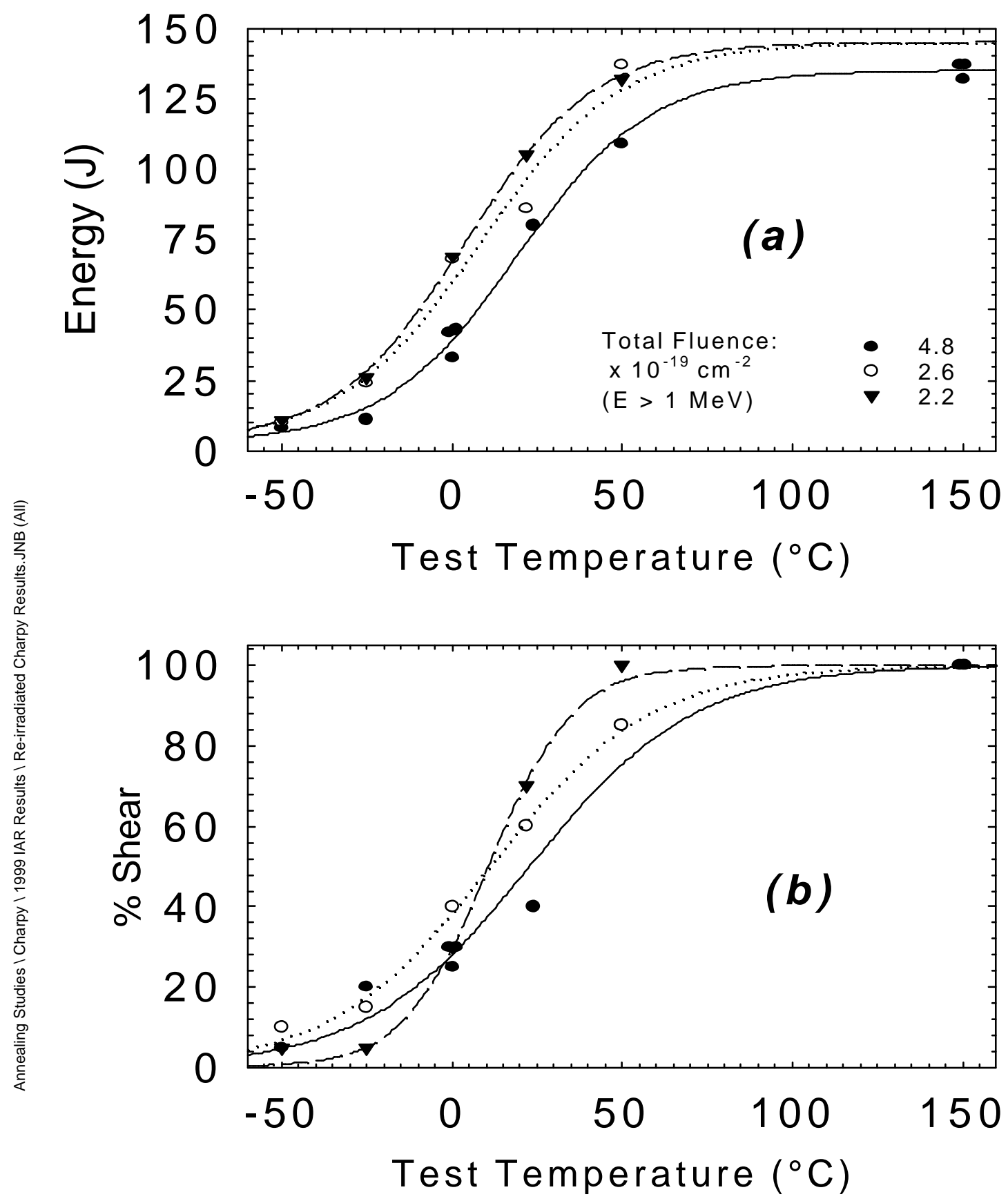

Figure 5 - Results of Charpy specimen testing: (a) Charpy energy, (b) percent shear, (c) lateral expansion as a function of temperature, and $(d)$ Charpy energy as a function of lateral expansion. 


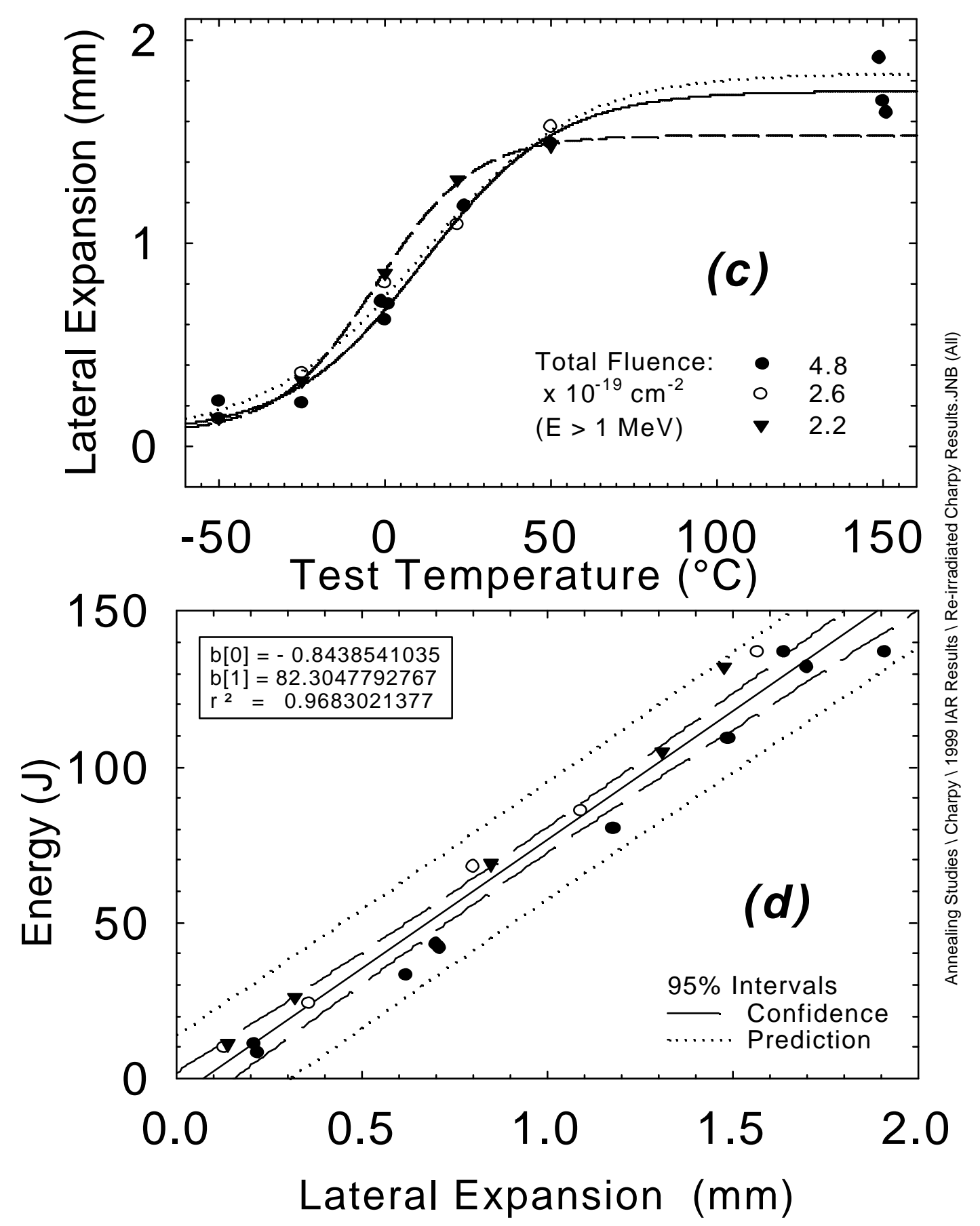

Figure 5 -(Continued) - Results of testing Charpy specimens: (a) Charpy energy, (b) percent shear, (c) lateral expansion as a function of temperature, and (d) Charpy energy as a function of lateral expansion. 


\section{REIRRADIATION OF HSSI WELD 73 W AFTER $454^{\circ} \mathrm{C}$ ANNEALS}

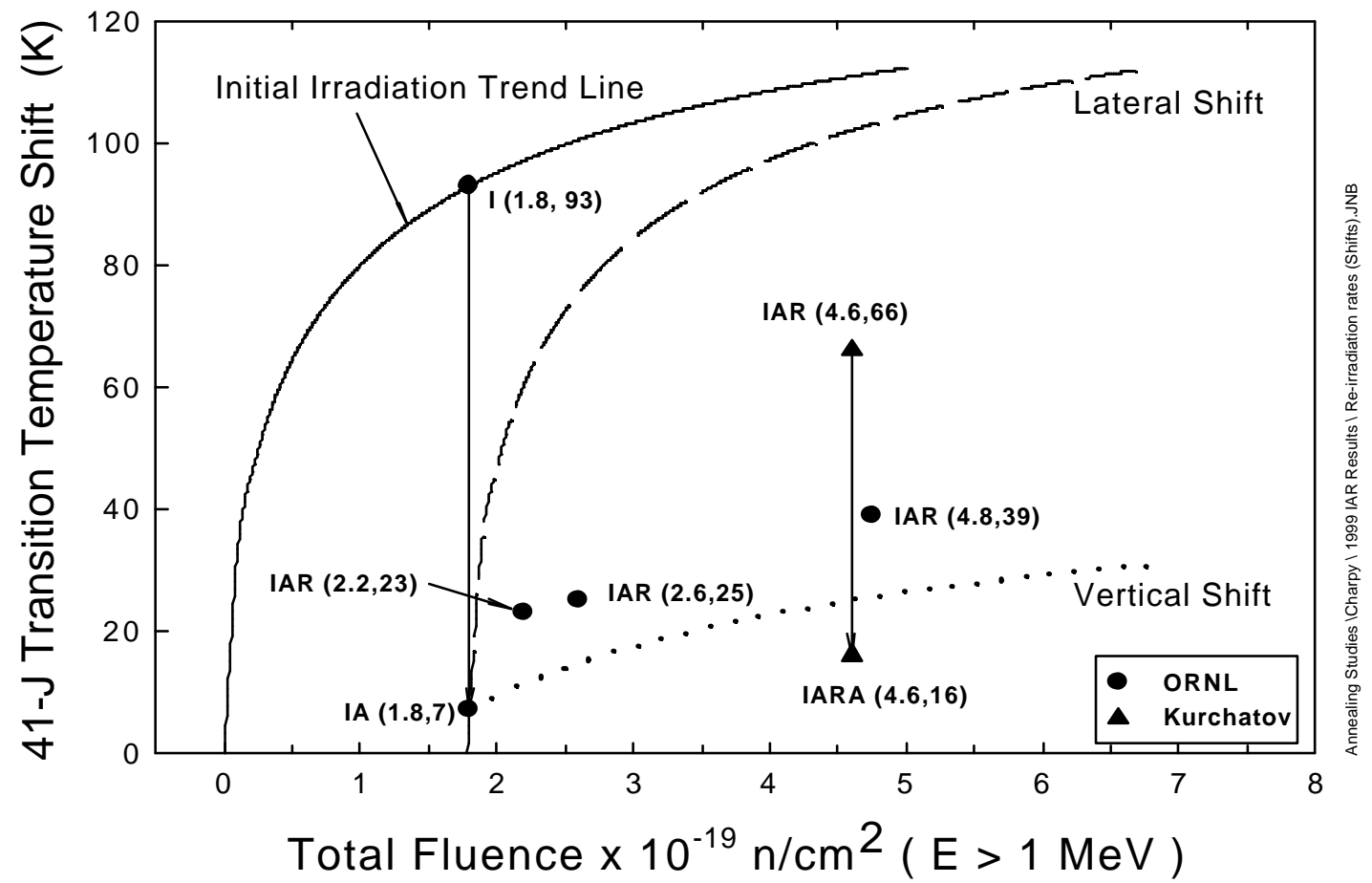

Figure 6 - Shifts in 41-J energy level transition temperature of irradiated, annealed, and reirradiated Charpy specimens versus total fluence.

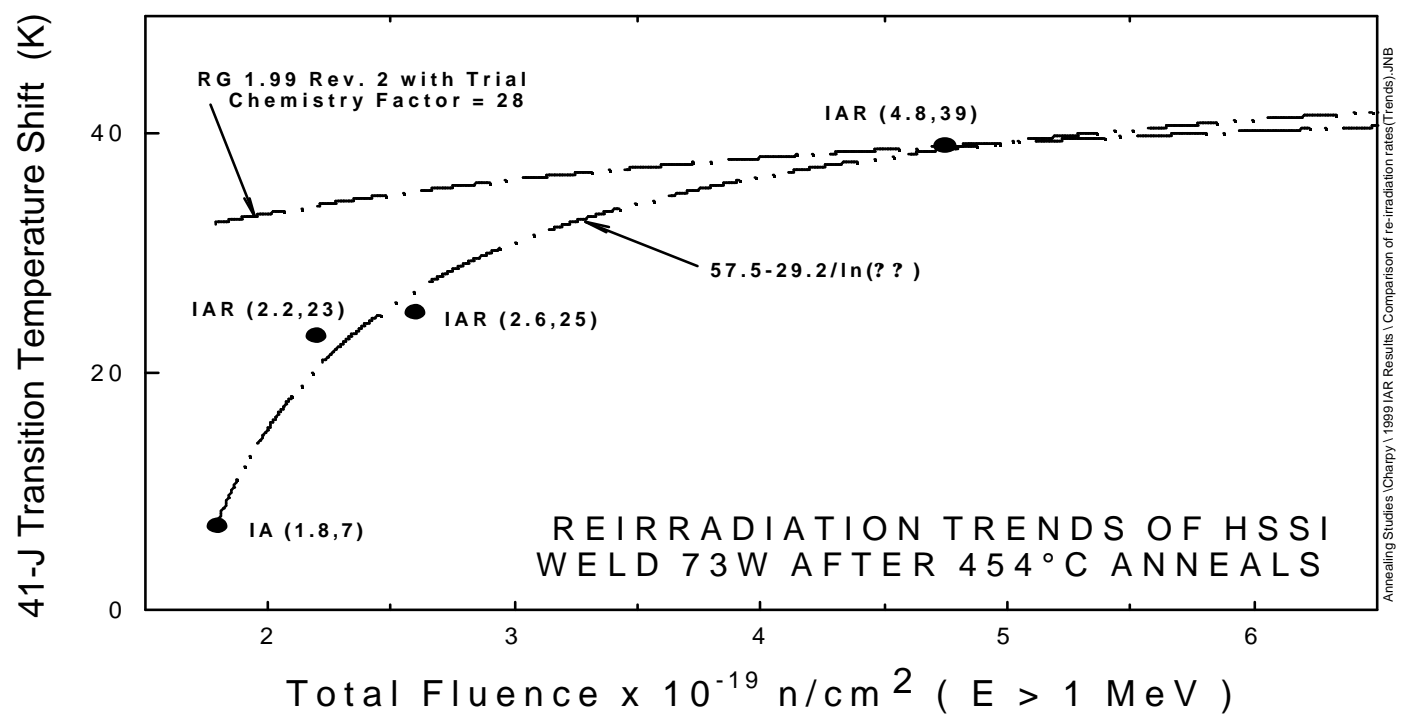

Figure 7 - Reirradiation trends obtained using expression given in $R G 1.99$, Rev 2, and a regression fit through the data. 
Research in progress at ORNL has given indications copper precipitates out of the matrix and is unavailable to cause further radiation embrittlement [15],[16]. Table 3 compares the amounts of copper under various conditions. The $0.12 \%$ at. wt $\mathrm{Cu}$ in the ferrite matrix that contributed to the embrittlement has been further reduced by precipitation to $0.06 \%$ at. wt. A small decrease in copper was also observed after the 168 -h anneal at $454^{\circ} \mathrm{C}$. No change in the matrix copper level was observed after reirradiation. The $0.04 \%$ at. wt. agrees reasonably in order of magnitude with the amount 0.02 inferred by curve fitting discussed above. The matrix composition was determined with a combination of an energy-compensated atom probe and an energy-compensated three-dimensional atom probe [17].

Table 3 - Comparison of bulk copper in HSSI Weld 73W in various conditions

\begin{tabular}{ll}
\hline Condition & Atomic \% \\
\hline $\begin{array}{l}\text { Bulk copper, at end of weld fabrication, postweld heat treatment (PWHT) } \\
\text { or stress relief at } 607^{\circ} \mathrm{C}\left(1125^{\circ} \mathrm{F}\right) \text { for } 40 \mathrm{~h}\end{array}$ & 0.27 \\
$\quad$ Matrix Copper, PWHT & 0.12 \\
Irradiated (I), $2 \times 10^{19} \mathrm{~cm}^{-2}(\mathrm{E}>1 \mathrm{MeV})$ & 0.06 \\
Irradiated and annealed (IA), $454^{\circ} \mathrm{C}\left(850^{\circ} \mathrm{F}\right)$ & 0.04 \\
$\quad$ Reirradiation (IAR), $1 \times 10^{19} \mathrm{~cm}^{-2}(\mathrm{E}>1 \mathrm{MeV})$ & 0.04 \\
\hline
\end{tabular}

\section{Summary and Conclusions}

The Charpy impact response of reirradiated HSSI Weld 73W has been determined at three fluence levels. The Charpy specimens had previously been irradiated and annealed at $454{ }^{\circ} \mathrm{C}$ for $168 \mathrm{~h}$, and the results have shown that the $\mathrm{OTT}_{41-\mathrm{J}}$ of the reirradiated specimens is slightly higher than predicted by the vertical shift method, but significantly less than predicted by the lateral shift method. Previous results have also shown that the USE over-recovers as a consequence of annealing, which may explain why the USE value after reirradiation is still approximately equal to the values of the unirradiated condition. One explanation of the relatively low rate of reembrittlement of HSSI Weld 73W compared to the initial rate may be the decreased availability of radiation sensitive elements such as copper to cause embrittlement. If the reembrittlement rate of an RPV can be shown to be significantly less than the initial one, then annealing may be a technically attractive consideration even before it becomes absolutely necessary.

\section{Acknowledgments}

This research is sponsored by the Office of Nuclear Regulatory Research, U.S. Nuclear Regulatory Commission, under Interagency Agreement DOE 1886-N695-3W with the U.S. Department of Energy under Contract DE-AC05-00OR22725 with UT-Battelle, LLC. It was performed in the Heavy-Section Steel Irradiation Program, managed by T. M. Rosseel. The authors appreciate the financial support from the U.S. Nuclear Regulatory Commission. The authors also appreciate the technical review by J. G. Merkle, manuscript 
preparation by J. L. Bishop, and many helpful suggestions from M. A. Sokolov and the efforts of the hot cell staff: L. J. Turner, P. S. Bishop, G. W. Parks, and the Charpy testing by R. L. Swain. The authors also acknowledge P. Pareige for measurements of the matrix copper compositions in the PWHT, I, and IA conditions shown in Table 3.

\section{References}

[1] Oland, C. B., Bass, B. R., Bryson, J. W., Ott, L. J., and Crabtree, J. A., Marble Hill Annealing Demonstration Evaluation, NUREG/CR-6552 (ORNL/TM-13446), Oak Ridge National Laboratory, Oak Ridge, Tenn., February 1998.

[2] Iskander, S. K., Sokolov, M. A., and Nanstad R. K., "Comparison of Different Experimental and Analytical Measures of the Thermal Annealing Response of NeutronIrradiated RPV Steels," Effects of Radiation on Materials: 18th International Symposium, ASTM STP 1325, R. K. Nanstad, M. L. Hamilton, F. A. Garner, and A. S. Kumar., American Society for Testing and Materials, West Conshohocken, PA, 1999.

[3] Iskander, S. K., Sokolov, M. A., and Nanstad, R. K., “A Perspective on Thermal Annealing of Reactor Pressure Vessel Materials from the Viewpoint of Experimental Results," ICONE-4, Proceedings of the ASME-JSME 4th International Conference on Nuclear Engineering, New Orleans, Louisiana, March 10-14, 1996, Vol. 1, Part A, ASME International, New York, 1996.

[4] Iskander, S. K., Sokolov, M. A., and Nanstad, R. K., "Effects of Annealing Time on the Recovery of Charpy V-Notch Properties of Irradiated High-Copper Weld Metal," Effects of Radiation on Materials: 17th Volume, STP 1270, D. S. Gelles, R. K. Nanstad, A. S. Kumar, and E. A. Little, Eds., American Society for Testing and Materials, Philadelphia, 1996, pp.277-293.

[5] Iskander, S. K., Sokolov, M. A., and Nanstad, R. K., "Some Aspects of the Role of Annealing in Plant Life Extension," Transactions of the American Nuclear Society, Vol. 71, La Grange Park, Illinois, 1994, pp. 191-192

[6] Kryukov, A. M., and Sokolov, M. A., "Investigation of Material Behavior Under Reirradiation after Annealing Using Subsize Specimens," Small Specimen Test Techniques Applied to Nuclear Reactor Vessel Thermal Annealing and Plant Life Extension, ASTM STP 1204, W. R. Corwin, F. M. Haggag, and W. L. Server, Eds., American Society for Testing and Materials, Philadelphia, 1993, pp. 417-423.

[7] Report on Annealing of the Novoronezh Unit 3 Reactor Vessel in the USSR, MPR-1230, MPR Associates, March 1991.

[8] "Format and Content of Report for Thermal Annealing of Reactor Pressure Vessels," Regulatory Guide 1.162, U.S. Nuclear Regulatory Commission, February 1996.

[9] "In-Place Dry Annealing of a PWR Nuclear Reactor Vessel," Code Case N-557, ASME Boiler and Pressure Vessel Code, Sect. XI, Div. 1, Approval Date March 19, 1996. 
[10] Eason, E. D., Wright, J. E., Nelson, E. E., Odette, G. R., and Mader, E. V., Models for Embrittlement Recovery Due to Annealing of Reactor Pressure Vessel Steels, NUREG/CR-6327 (MCS 950302), Modeling and Computing Services/University of California, Santa Barbara, May 1995.

[11] Stallman, F. W., Wang, J. A., and Kam, F. B. K., TR-EDB: Test Reactor Embrittlement Data Base, Version 1, NUREG/CR-6076 (ORNL/TM-12415), Martin Marietta Energy Systems, Inc., Oak Ridge National Laboratory, Oak Ridge, Tenn., January 1994.

[12] "Radiation Embrittlement of Reactor Pressure Vessel Materials," Regulatory Guide 1.99, Revision 2, U.S. Nuclear Regulatory Commission, Washington, May 1988.

[13] Nanstad, R. K., McCabe, D. E., Menke, B. H., Iskander, S. K., and Haggag, F. M., "Effects of Irradiation on $\mathrm{K}_{\mathrm{Ic}}$ Curves for High-Copper Welds," Effects of Radiation on Materials, 14th International Symposium, (Volume II), ASTM STP 1046, N. H. Packan, R. E. Stoller, and A. S. Kumar, Eds., American Society for Testing and Materials, Philadelphia, 1990, pp. 214-233.

[14] Sokolov, M. A., Chernobaeva, A. A., Nanstad, R, K. Nikolaev, Y. A., and Korolev, Y. N., "Irradiation, Annealing, and Reirradiation Effects on American and Russian Reactor Pressure Vessel Steels,'Effects of Radiation on Materials: 19th International Symposium, ASTM STP 1366, M. L. Hamilton, A. S. Kumar, S. T. Rosinski, and M. L. Grossbeck, Eds., American Society for Testing and Materials, West Conshohocken, PA, 2000, pp. 415-434.

[15] Pareige, P., Stoller, R. E., Russell, K. F., and Miller, M. K., “Atom Probe Characterization of the Microstructure of Nuclear Pressure Surveillance Materials after Neutron Irradiation and after Annealing Treatments," Journal of Nuclear Materials, 249, 165-174 (1997).

[16] Miller, M. K., and Russell, K. F., “Atom Probe Characterization of Copper Solubility in the Midland Weld after Neutron Irradiation and Thermal Annealing," Journal of Nuclear Materials, 250, 223-228 (1997).

[17] Miller, M. K., Atom Probe Tomography, Kluwer Academic/Plenum Publisher, 2000. 